TRANSCENDING BLACKNESS 



\title{
TRANSCENDING BLACKNESS
}

\author{
$\overline{-}$ \\ From the New Millennium Mulatta \\ to the Exceptional Multiracial
}

RALINA L. JOSEPH

DUKE UNIVERSITY PRESS

DURHAM AND LONDON 2013 
(C) 2013 Duke University Press

All rights reserved

Printed in the United States of America on acid-free paper @

Designed by Heather Hensley

Typeset in Whitman by Tseng Information Systems, Inc.

Library of Congress Cataloging-in-Publication Data appear on the last printed page of this book. 
FOR JJ, TJ, AND NV

$\overline{-}$ 
